\title{
Hemiasterella aristoteliana n. sp. (Porifera, Hadromerida) from the Aegean Sea with a discussion on the family Hemiasterellidae
}

\author{
Eleni Voultsiadou-Koukoura ${ }^{1}$ \& R.W.M. van Soest ${ }^{2}$ \\ ${ }^{1}$ Department of Zoology, University of Thessaloniki, 54006 Thessaloniki, Greece; ${ }^{2}$ Institute of Taxonomic \\ Zoology (Zoological Museum), University of Amsterdam, P.O. Box 4766, 1009 AT Amsterdam, The \\ Netherlands
}

Keywords: Taxonomy, Hemiasterella, Hadromerida, Mediterranean

\begin{abstract}
A representative of the genus Hemiasterella Carter, 1879 was found for the first time in the Mediterranean Sea during sampling in the shallow waters of the northern Aegean Sea. The new species, $H$. aristoteliana, is compared with Atlantic Hemiasterella elongata Topsent, 1928. The status of the family Hemiasterellidae is discussed.
\end{abstract}

\section{Résumé}

Une espèce nouvelle du genre Hemiasterella Carter, 1879 est décrite provenant du nord de la Mer Egée (Grèce). C'est la première fois que une Hemiasterella est récoltée dans la Méditerranée. La nouvelle espèce est comparée avec Hemiasterella elongata Topsent, 1928 de l'Atlantique. L'état systématique de la famille Hemiasterellidae est discuté.

\section{Introduction}

Ten species of the genus Hemiasterella Carter, 1879 are currently known worldwide: $H$. typus and $H$. affinis both described by Carter (1879) from Australia, H. (Epallax) callocyathus (Sollas, 1888) from Indonesia, $H$. vasiformis (Kirkpatrick, 1903), $H$. vasiformis minor (Kirkpatrick, 1903), H. complicata Topsent, 1919, H. intermedia Dendy, 1922, and $H$. strongylophora Lévi, 1956 from the Indian Ocean, $H$. digitata Burton, 1929 from Antarctica, and finally $H$. elongata Topsent, 1928 from deep waters $(875 \mathrm{~m})$ off the Cape Verde Islands (North Atlantic Ocean).

Recent collecting activities, by scuba diving, in the northern Aegean Sea, yielded material belonging to the genus Hemiasterella not represented till now in the Mediterranean. The four specimens collected could not be classified as one of the already known species of the genus.

The purpose of the present paper is to give a detailed description of the new species and to compare it with the zoogeographically and morphologically closest species $H$. elongata Topsent, 1928.

A recent evaluation of the status of the order Axinellida (cf. Van Soest, in press), to which the genus (as a member of the family Hemiasterellidae Von Lendenfeld, 1889) is usually attributed, necessitates the provisional reassignment of it to the order Hadromerida, based on the possession of aster microscleres. This in turn requires an emendation of Hooper's (1986) recent definitions of the family and its genera. The generic content of the family Hemiasterellidae is briefly discussed below.

\section{Systematic description}

Order uncertain

(?Hadromerida Topsent, 1928)

Family Hemiasterellidae Von Lendenfeld, 1889

Genus Hemiasterella Carter, 1879 


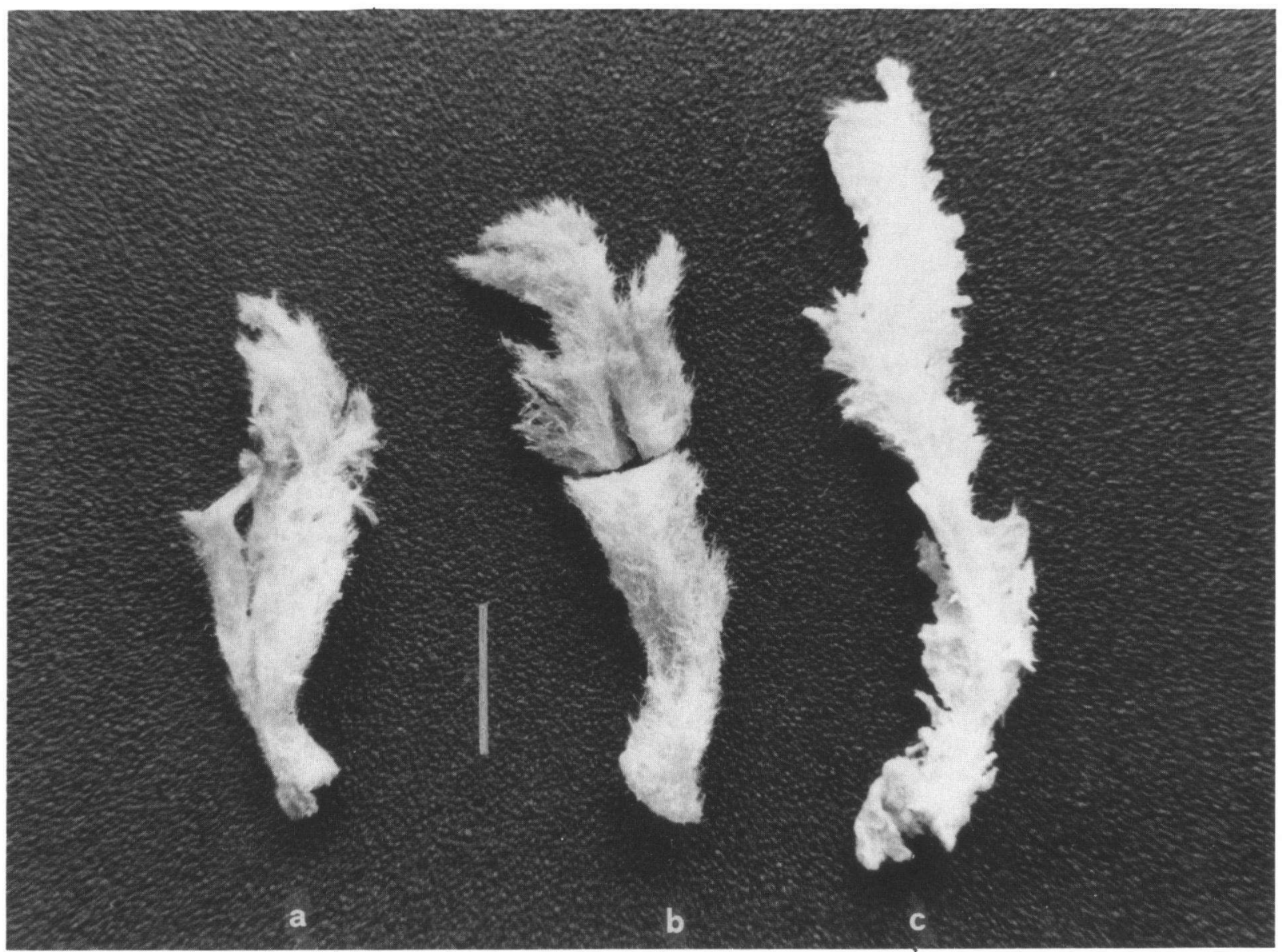

Fig. l. Hemiasterella aristoteliana $\mathrm{n}$. sp.: a, holotype; b and c, paratypes 1 and 2 (scale: $1 \mathrm{~cm}$ ).

\section{Hemiasterella aristoteliana $\mathrm{n} . \mathrm{sp}$.}

Material. - Holotype: Zoological Museum Amsterdam (ZMA) coll. no. ZMA POR 8766, Cape Drepanon, Sithonia Peninsula, Aegean Sea, 8 July 1986.

Paratypes: Museum of the Department of Zoology, University of Thessaloniki, (1) Ga 4510, Cape Drepanon, Sithonia Peninsula, Aegean Sea, 8 July 1986, (2) Ga 4511, Youra Island, northern Sporades Islands, Aegean Sea, 19 October 1988, (3) Ga 4512, Cape Drepanon, Sithonia Peninsula, Aegean Sea, 8 July 1986.

Description. - Shape and size: The holotype and paratypes 1 and 2 (Fig. 1) are single erect branches, lamellate and crooked, fusing laterally, thus forming an intricate margin. They have longitudinal flutings being somewhat angular in cross-section. They are more slender near their base, becoming broader in their upper part; the holotype is almost fan-shaped. However, a real peduncle is not clearly distinguishable. On their bases there are remains of the hard substrate to which they were attached. The holotype has a height of $3.5 \mathrm{~cm}$ and a maximum width of $1 \mathrm{~cm}$. The dimensions of paratype 1 are $4.2 \times 1 \mathrm{~cm}$, and those of paratype $25.5 \times 1 \mathrm{~cm}$. Paratype 3 is an almost rectangular piece measuring $3.4 \times 1.2 \mathrm{~cm}$; no base of attachment can be recognized.

Colour: Light orange in life, whitish beige in formalin.

Consistency: Moderately soft, flexible and fragile.

Surface: Uneven, very hispid. No special ectosome can be recognized.

Skeleton: Plumoreticulate structure (Fig. 2); 


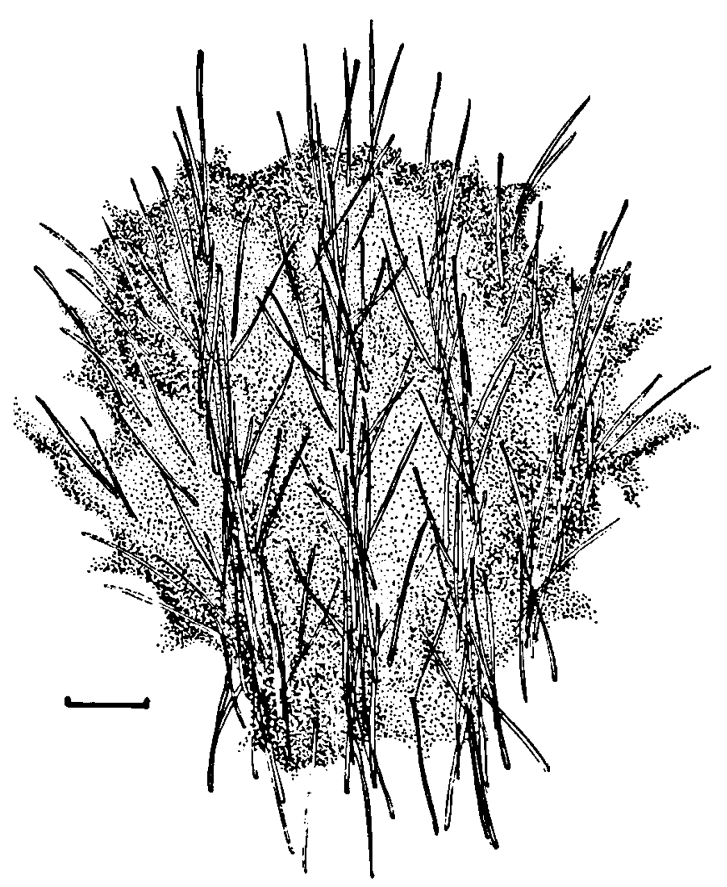

Fig. 2. Skeletal structure of Hemiasterella aristoteliana n. sp (scale: $1 \mathrm{~mm}$ ).

columns and cross-connections made of styles. Some of the styles project, giving rise to the hispidity of the surface. Columns are surrounded by very abundant asters which in some places are kept together by a small amount of spongin. Asters are deposited very densely, especially in the vicinity of the sponge surface.

Spicules: Styles (Figs. 3a, c) are smooth, straight or slightly curved, measuring $1800-3000$ by $18-$ $37 \mu \mathrm{m}$. Asters (Fig. 3b) are strongylasters with more or less pointed rays. Their maximum diameter is $13-42 \mu \mathrm{m}$ (mean max. diameter 25.1-27.5 $\mu \mathrm{m}$ (Fig. 4, see discussion). The number of rays ranges between 1 and 12 . The asters with 1,2 , or 3 rays are abundant in the holotype but they are also present in good numbers in the paratypes. Some asters or even some rays in a certain aster are smooth but the vast majority are more or less spined.

Remarks: A variable number of spicules, not considered as proper, has been found. In the holotype, small oxeas, styles and centrotolyte strongyles and a few sinuous strongyles were observed. In paratypes 1 and 3 which came from the same area as the holotype, besides the above spicule types, long straight strongyles were found. Finally, in paratype 2 a number of sinuous strongyles existed.

Habitat. - The holotype and paratypes 1 and 3 were found in semi-dark environments, among rocks covered with algae, at a depth of 12-15 m. Paratype 2 was collected in a semi-dark cave at a depth of $22 \mathrm{~m}$.

Etymology. - The species is named after the ancient Greek philosopher Aristotle.

Comparisons. - Hemiasterella elongata Topsent, 1928 (with probable synonym Vibulinus mutilus Topsent, 1928) is one of the two Hemiasterella species which do not have the typical vase form of the other species of the genus (the other is $H$. digitata Burton, 1929, from Antarctica, which is palmatodigitate). Based on the examination of a specimen collected from the Cape Verde Islands and preserved in the Zoological Museum Amsterdam, coll. no. ZMA POR 7432, and taking into account the original description of the species given by Topsent (1928), we constructed Table I giving the differences in spiculation between $H$. aristoteliana and $H$. elongata.

As can be seen from Table I, the size of the spicules of $H$. aristoteliana is much greater than that of $H$. elongata (including that of the probable synonym Vibulinus mutilus, cf. Topsent, 1928). Although there is a clear difference in the size of styles, those of the new species being almost out of the size range found for $H$. elongata, the more striking difference is found in the size of strongylasters.

In order to examine this difference, 100 strongylasters were measured from three specimens of $H$. aristoteliana and from the single available specimen of $H$. elongata. In all cases the maximum diameter of the strongylaster, including the length of the rays, was measured. Means for all groups at $95 \%$ confidence limits and coefficients of variation were calculated. From Fig. 5 it can be seen that the mean maximum diameters observed in $H$. aristoteliana range from 25.1 to $27.5 \mu \mathrm{m}$, while that of $H$. elongata is only $16.9 \mu \mathrm{m}$, agreeing with Top- 
Table I. Skeletal differences between Hemiasterella aristoteliana n. sp. and $H$. elongata Topsent, 1928

\begin{tabular}{llll} 
& Hemiasterella aristoteliana $\mathrm{n.sp}$. & & Hemiasterella elongata Topsent \\
\cline { 3 - 4 } & & ZMA specimen & Topsent's original description \\
\hline Styles & $1800-3000 \times 18-37 \mu \mathrm{m}$ & $550-1800 \times 22-36 \mu \mathrm{m}$ & $1500-2000 \times 25-60 \mu \mathrm{m}$ \\
Oxeas & no oxeas found & rare $600-1500 \mu \mathrm{m}$ & rare $1900-2345 \mu \mathrm{m}$ \\
Diameter of asters & $13-42 \mu \mathrm{m}$ & $12-18 \mu \mathrm{m}$ & $15-18 \mu \mathrm{m}$ \\
No. of aster rays & $1-12$ & $8-13$ & $\approx 12$ \\
\hline
\end{tabular}

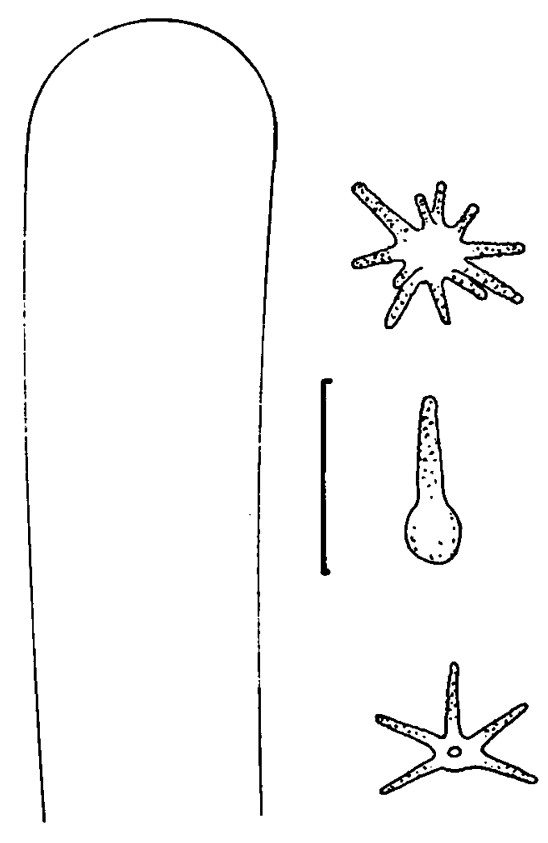

a
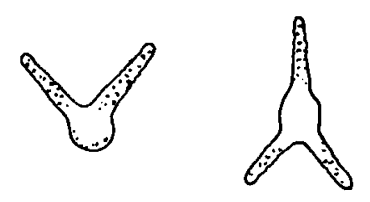<smiles>C1CCCCC1</smiles>
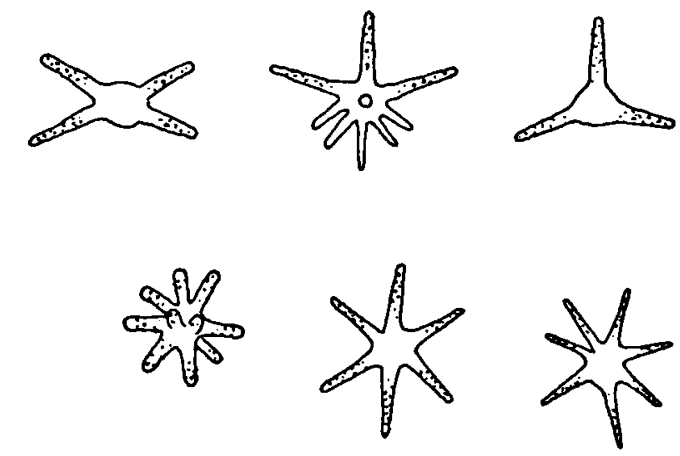

b

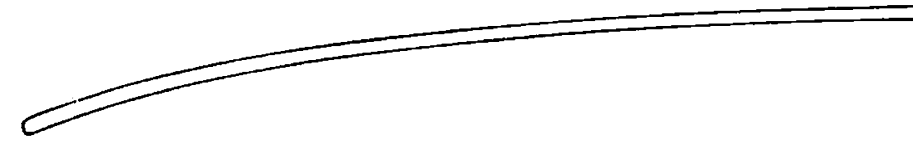

C

Fig. 3. Spicules of Hemiasterella aristoteliana n. sp.: a, base of a style; b, strongylasters; c, styles (scale a \& b: $25 \mu \mathrm{m}, \mathrm{c:} 500 \mu \mathrm{m}$ ).

sent's measurements for the species, ranging between 15 and $18 \mu \mathrm{m}$.

Furthermore, as mentioned above, there is a great variation in the number of rays $(1-12)$ of the strongylasters in $H$. aristoteliana, while in $H$. elongata this number constantly varies between 8 and 13
( $\approx 12$ according to Topsent). No differences were observed in the disposition of the skeleton between the two species.

Besides the differences in spiculation, there are also differences in the habitats of the two species: $H$. elongata was found at depths of $875 \mathrm{~m}$ and 


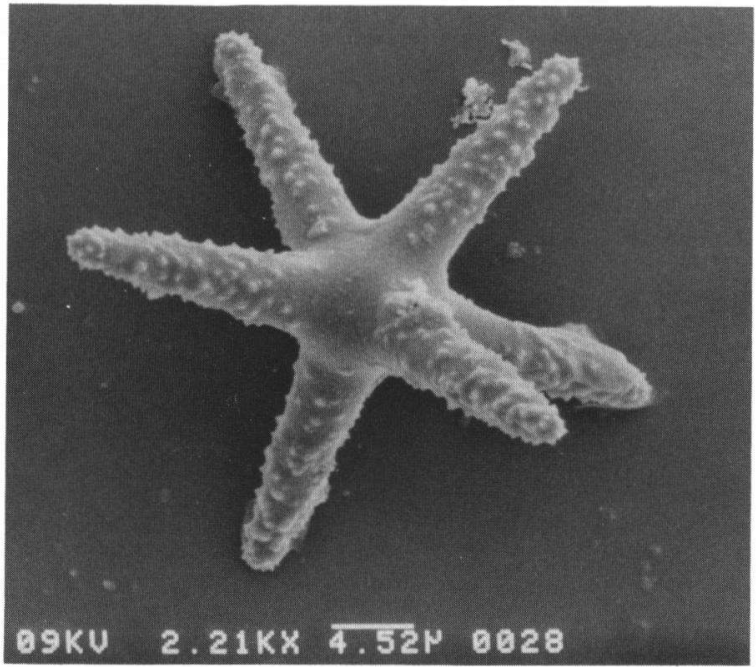

Fig. 4. SEM photograph of aster of Hemiasterella aristoteliana n. sp.

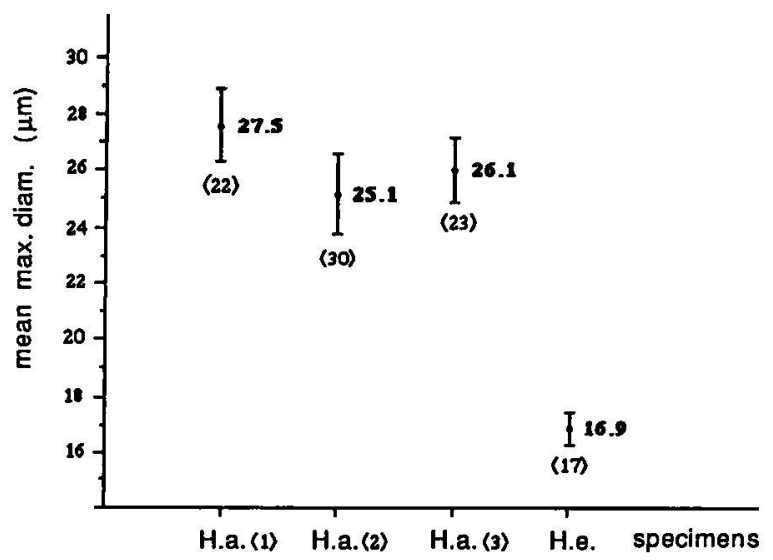

Fig. 5. Mean ( $95 \%$ confidence limits) maximum diameter of strongylasters (coefficient of variation in parentheses; H.a. = Hemiasterella aristoteliana, H.e. $=H$. elongata .

$130 \mathrm{~m}$ near the Cape Verde Islands and at $116 \mathrm{~m}$ off Morocco (Vibulinus mutilus), while $\boldsymbol{H}$. aristoteliana occurs in shallow waters (12-22 m).

Hemiasterella digitata from Antarctic waters has a ramose habit and its styles are much shorter (only up to 1000 by $22 \mu \mathrm{m}$ ); asters in this species are only up to $27 \mu \mathrm{m}$ and ray number varies from 6 to 10 (Burton, 1929).

The remaining 8 species of the genus Hemiasterella, besides having the typical vase shape, all come from different zoogeographic areas.

\section{Discussion on the family Hemiasterellidae}

The family Hemiasterellidae Von Lendenfeld (1889) was discussed recently by Hooper (1986) in the course of a revision of the Australian genus Axos Gray (1867). Although we endorse most of Hooper's conclusions, some additional remarks and emendations are necessary.

Firstly, the diagnosis of the family needs emendation, because most contemporary authors (including Hooper in his Axos paper) considered Hemiasterellidae to be members of an "order" Axinellida, which has recently been shown to be a polyphyletic assemblage (Hooper, in press; Van Soest, in press). The simple definition "Axinellida(e) with stellate microscleres" (Von Lendenfeld, 1889) cannot be maintained because stellate microscleres are a synapomorphy for the assemblage of Tetractinellida and Hadromerida (Van Soest, in press), and thus constitute an ancestral character unfit for defining a family belonging to this assemblage.

Hemiasterellidae share their monactinal megascleres with the Hadromerida and for that reason they may be provisionally included in that order. However, through their axially condensed choanosomal skeletons (however, loosely constructed in some members) and extra-axial specialization (bouquets, tracts or single spicules), they differ clearly from typical hadromerid forms as Polymastia and Spirastrella. Also, the predominance of styles, rather than tylostyles, is unusual in the Hadromerida, being only found in Aaptos and Tethyidae. The retention of long oxeas in several species of Hemiasterellidae is noteworthy, and likewise unusual for Hadromerida.

Definition. - Hemiasterellidae: Hadromerida with an ectosomal crust of euasters and a choanosomal skeleton consisting of axially condensed masses of long styles and/or oxeas and extra-axial single styles and/or bouquets of smaller styles and/or oxeas.

This definition differentiates Hemiasterellidae from Jaspis Gray (1867) (?family Coppatiidae), in which megascleres are diactinal and confusedly arranged in the interior, whereas a subectosomal tangential arrangement carries the crust of euasters. Aster morphology in several species of Jaspis, in- 
cluding the type-species J. johnstoni (Schmidt, 1862), is closely similar to that of Hemiasterella, and a future revision of Jaspis may show these genera to be closely related.

The definition of Hemiasterellidae cited above seems to exclude non-axial forms, such as Paratimea Hallmann (1916); however, that genus is so similar to the axially condensed Stelligera Gray (1867), that a close relationship between the two is obvious and secondary loss of axial construction must be assumed. Whether that also applies to Xenospongia Gray (1867) remains undecided; Dendy's (1905) minute description of $X$. patelliformis makes it clear that it has several characters in common with Tethya (diversity of asters, possession of an organic cortex).

Our view on the generic content of the Hemiasterellidae thus is in accordance with Hooper (1986); his definitions, however, need to be emended.

\section{Proposed classification of Hemiasterellidae}

\section{Genus Hemiasterella Carter, 1879}

Synonyms: Epallax Sollas, 1888, and Kalastrella Kirkpatrick, 1903

Diagnosis. - Hemiasterellidae with loosely arranged "axial" and extra-axial skeleton consisting of styles and/or oxeas, without functional categories of megascleres; asters typically with thick, acanthose, strongylote rays; habit vasiform, platelike or with flattened branches.

Distribution: Indian and West Pacific Ocean, Antarctic, East Atlantic, eastern Mediterranean.

Species described: $H$. typus Carter (1879) (type-species) (?Australia, cf. Dendy, 1922), $H$. affinis Carter (1879) (origin unknown), H. callocyathus (Sollas, 1888, as Epallax) (N. Australia; specimen in ZMA, POR 8435, from Papua New Guinea), H. vasiformis (Kirkpatrick, 1903, as Kalastrella) (South East Africa), H. minor (Kirkpatrick, 1903, as Kalastrella) (South East Africa), $H$. complicata Topsent (1919) (=Alcyonium vasculum Lamarck inédite, cf. Topsent, 1933: 45) (type-locality: Madagascar, specimens in ZMA, POR 2832 and 3233, from Indonesia), $H$. intermedia Dendy (1922) (Indian Ocean; specimen in ZMA, POR 2773, from Indonesia), $H$. elongata Topsent, 1928 (Cape Verde Islands; topotypical specimen in ZMA, POR
7432) (probable junior synonym: Vibulinus mutilus Topsent, 1928, from Morocco), $H$. digitata Burton (1929) (Antarctica), H. strongylophora Lévi (1956) (Madagascar), H. aristoteliana $\mathrm{n}$. sp. (Aegean Sea).

\section{Genus Adreus Gray, 1867}

Diagnosis. - Hemiasterellidae with strongly developed axial skeleton consisting of long styles only, and ill-developed extra-axial skeleton consisting of bouquets of smaller styles; asters typically with thin, strongylote or tylote rays, which may be branched; habit with thin, stiff branches. Distribution: East Atlantic, Carribean.

Species described: A. fascicularis (Bowerbank, 1866, as Dictyocylindrus) (type-species) (British Isles, topotypical specimens in ZMA, POR 6159), A. micraster (Burton, 1956, as Vibulinus) (West Africa, specimens in ZMA, POR 6837 and 6860, from Mauritania), A. stylifera (Arndt, 1927, as Timea) (typespecimen in ZMA, POR 2391, and many topotypical specimens from Curaçao).

\section{Genus Stelligera Gray, 1867}

Synonym: Vibulinus Gray, 1867

Diagnosis. - Hemiasterellidae with strongly developed axial skeleton of long styles and oxeas, and "raspailid" extra-axial skeleton consisting of bouquets of small styles surrounding a central long style, which projects beyond the crust of euasters; the latter are thick-centered, short-rayed oxyspherasters; habit arborescent.

Distribution: East Atlantic, Mediterranean.

Species described: S. stuposa (Montagu, 1818) (British Isles, many specimens in ZMA from Ireland and France) [possible junior synonyms: S. rigida Montagu, 1818 (British Isles), S. stelligera (Schmidt, 1862, as Raspailia) (type-species from the Adriatic) and S. nux Von Lendenfeld (1896) (Mediterranean)]; $S$. columnata Lévi (1959) (West Africa, topotypical specimens in ZMA, POR 7309 and 7546, from the Cape Verde Islands).

\section{Genus Paratimea Hallmann, 1916}

Diagnosis. - Hemiasterellidae with (extra-axial) skeleton consisting of long tylostyles erect on the substrate, surrounded by smaller centrotylote oxeas; microscleres are thick-centered, short rayed oxyspherasters; habit thinly incrusting.

Distribution: Mediterranean, East Atlantic, $\mathrm{Ca}$ ribbean. 
Species described: $P$. constellata (Topsent, 1893, as Bubaris) (type-species) (Mediterranean, specimens in ZMA, POR 7348, from the Cape Verde Islands), $P$. galaxea De Laubenfels (1936) (Florida), and several "species" of uncertain status: $P$. duplex Topsent (1927, as Halicnemia) (Morocco), P. pierantonii Sarà, 1958 (Naples), $P$. oxeata Pulitzer-Finali, 1978 (Naples).

\section{Genus Axos Gray, 1867}

Synonym: Echinospongia Gray, 1870 (see Hooper, 1986)

Diagnosis. - Hemiasterellidae with strongly developed axial skeleton of styles, with extra-axial skeleton of long spicule tracts protruding at right angles to the axis and forming characteristic surface conules; asters hexaradiate to cruciform, with thick heavily spined rays; habit ramose or flabelliform.

Distribution: N.W. Australia.

Species described: A. cliftoni Gray (1867) (N.W. Australia; topotypical specimen in ZMA, POR 6167, donated by J.N.A. Hooper), A. flabelliformis Carter (1879) (W. Australia).

\section{References}

Arndt, W., 1927. Kalk- und Kieselschwämme von Curaçao. Bijdr. Dierk., 25: 133-158.

Bowerbank, J.S., 1866. A monograph of the British Spongiadae. II: 1-388 (Ray Society, London).

Burton, M., 1929. Porifera. Part II. Antarctic sponges. Nat. Hist. Rep. Br. Antarct. Terra Nova Exped., (Zool.) 6(4): 393-458.

Burton, M., 1956. The sponges of West Africa. Atlantide Rep., 4: 11-147.

Carter, H.L., 1879. On Holostrella, a fossil sponge of the Carboniferous era, and on Hemiastrella, a new genus of recent sponges. Ann. Mag. nat. Hist., (5)3: 141-150.

Dendy, A., 1905. Report on the sponges collected by Professor Herdman, at Ceylon, in 1902. Rep. Pearl Oyster Fisheries Gulf of Manaar 3, Suppl. 18: 57-246 (Royal Society, London).

Dendy, A., 1922. Report on the Sigmatotetraxonida collected by H.M.S. "Sealark" in the Indian Ocean. In: Report of the Percy Sladen Trust Expedition to the Indian Ocean in 1905, Vol. 7. Trans. Linn. Soc. London, (Zool.) 18: 1-164.

Gray, J.E., 1867. Notes on the arrangement of sponges, with a description of some new genera. Proc. zool. Soc. London, 1867: 492-558.

Gray, J.E., 1870. Note on a new genus of sponge from West Australia. Ann. Mag. nat. Hist., (4)6: 272.

Hallmann, E.F., 1916. A revision of the genera with microscleres included, or provisionally included, in the family Axinellidae, with descriptions of some Australian species.
Parts i-iii. Proc. Linn. Soc. N.S.W., 41(3-4): 453-491, 495-552, 634-675.

Hooper, J.N.A., 1986. Revision of the marine sponge genus Axos Gray (Demospongiae: Axinellida) from North-West Australia. The Beagle, Occ. Pap. Northern Territory Mus. Arts Sci., 3(1): 167-189.

Hooper, J.N.A., in press. Character stability, systematics and affinities between Microcionidae (Poecillosclerida) and Axinellida. Proc. 3rd int. Conf. Biol. Sponges, Woods Hole, 1985.

Kirkpatrick, R., 1903. Descriptions of South African sponges. Part III. Mar. Invest. S. Afr., 2: 233-264.

Laubenfels, M.W. de, 1936. A discussion on the sponge fauna of the Dry Tortugas in particular, and the West Indies in general, with material for a revision of the families and orders of the Porifera. Pap. Tortugas Lab., 30: i-iii, 1-225.

Lendenfeld, R. von, 1889. A monograph on the horny sponges: i-iv, 1-936 (Trübner \& Co., London).

Lendenfeld, R. von, 1896. Die Clavulina der Adria. Nova Acta Acad. Caesar. Leop. Carol., 69(1): 1-251, pls. I-XII.

Lévi, C., 1956. Spongiaires des côtes de Madagascar. Mém. Inst. scient. Madagascar, (A)10: 1-23.

Lévi, C., 1959. Campagne de la "Calypso": Golfe de Guinée. Spongiaires. Annls. Inst. océanogr., 37: 115-141.

Montagu, G., 1818. An essay on sponges with descriptions of all the species that have been discovered on the coast of Great Britain. Mem. Wernerian nat. Hist. Soc., 2(1): 67-122.

Pulitzer-Finali, G., 1978. Report on a collection of sponges from the Bay of Naples. III. Hadromerida, Axinellida, Poecilosclerida, Halichondrida, Haplosclerida. Boll. Musei Ist. biol. Univ. Genova, 45: 7-89.

Sarà, M., 1958. Studio sui Poriferi di una grotta di marea del Golfo di Napoli. Archivio zool. ital., 43: 203-281.

Schmidt, O., 1862. Die Spongien des Adriatischen Meeres: 1-88 (Engelmann, Leipzig).

Soest, R.W.M. van, in press. Demosponge higher taxa classification reexamined. In: H. Keupp \& J.E. Reitner (eds.), Fossil and recent sponges (Springer Verlag, Berlin).

Sollas, W.J., 1888. Report on the Tetractinellida collected by H.M.S. "Challenger" during the years 1873-1876. Rep. scient. Results Voy. Challenger, (Zool.) 25: i-clxvi, 1-458, pls. I-XLIV, 1 map.

Topsent, E., 1893. Nouvelle série de diagnoses d'Eponges de Roscoff et de Banyuls. Archs. Zool. exp. gén., (3)1: xxxiii-xliii.

Topsent, E., 1919. Notes sur les genres Semisuberites et Hemiasterella. Bull. Inst. oceanogr. Monaco, 359: 1-11.

Topsent, E., 1927. Diagnose d'Eponges nouvelles recueillies par le Prince Albert I. Bul. Inst. océanogr. Monaco, 502: 1-19.

Topsent, E., 1928. Spongiaires de l'Atlantique et de la Méditerranée provenant des croisières du Prince Albert ler de Monaco. Résult. Camp. scient. Prince Albert I, 74: 1-376, [377-399], pls. I-XI.

Topsent, E., 1933. Eponges de Lamarck conservées au Muséum de Paris. Archs. Mus. natn. Hist. nat. Paris, 10: 1-60.

Received: 29 August 1990

Revised: 18 December 1990 